\title{
This means war
}

\section{Does a role-playing game reveal any new insights into the factors holding back the UK biotech sector?}

Take two biotech start-ups with precisely the same preclinical cancer portfolio at exactly the same time. Put one in Europe and take the other to the United States. Which one will build a $\$ 2$ billion market cap company first?

That's what the Bioscience Futures Forum (BFF), an expert group formed by the UK government's Department for Business, Enterprise \& Regulatory Reform, asked a role-playing war game developed by a University of London start-up Simulstrat. BFF wanted to generate some high-level answers and actions for an upcoming review of biotech-related policy due to be submitted to the UK government this fall. The UK government might not want to hear the answer.

How did the game work? Both the US team, Sam BioPharma (named for its 'uncle') and the UK team, Sim BioPharma (named for simulation, not simian) started as university spin-offs with a promising lead compound product that was a potent, selective, specific and orally administered treatment for solid tumors. Both took their companies through funding rounds (at simulated two-year intervals). The real UK management of Sim presented to real UK investors; the real US executives of Sam interacted with real US investors. The two investor groups had identical funds, with equal amounts available for future investment.

The first funding round was designed to put the compound into the clinic. And immediately there was a huge divergence in outcomes.

Sim BioPharma presented a virtual company business plan, outsourcing many aspects of the organization. They attracted $\$ 6$ million to fund one phase 1 trial, with a second tranche of $\$ 20$ million available for phase 2 trials if phase 1 turned out positive. In contrast, Sam BioPharma soughtand received - $\$ 15$ million for a phase 1 trial and two phase 2 studies, one in a primary indication (colorectal cancer) and another in breast cancer. If Sam met development milestones, the amount could increase to \$45 million.

In the next move, the companies were told their compound had completed a successful phase 1 trial and they now needed to raise further capital for phase 2 . The primary public market was about to take a downturn, and independent researchers had made skeptical comments about their compounds. The companies pondered initial public offerings, pharma co-development partnerships, royalty deals and marketing rights. And the game supervisors added a further twist: a pharma company wanted to acquire the company.

Sam BioPharma declined the buyout, but offered the pharma company marketing rights outside the United States. Armed with the deal, it went public on NASDAQ, with US investment bankers enabling it to raise $\$ 100$ million.

Sim also turned down the acquisition, but didn't float: it rejected the UK Alternative Investment Market (AIM), where it could have raised \$50 million, because of lack of liquidity, and rejected NASDAQ because of the high cost of Sarbanes-Oxley compliance. Instead, it took a private round to fund phase 2 work, with the UK investors opting to fund research until they got an improved pharma offer.
Then came a setback. To test the resilience of each team, Sim and Sam were told their phase 2 trial had missed its primary endpoints, but still showed evidence of efficacy.

The US team acted much more decisively and bullishly, holding a mock press conference to explain the results and emphasize its other development programs that stemmed from its broader financing base and built-in strategic contingency. In contrast, the setback hit the UK team badly because its whole business was reliant on the single lead indication; there was no plan B.

So what could the observers of the game and its players make of the outcomes?

Well, they could — and indeed did — conclude that the biotech finance marketplace in the United Kingdom is weak. AIM has little liquidity and virtually no follow-on market. Preemption rights allow existing shareholders to block potentially diluting but opportunistic fundraising rounds, such as private investments in public equity. And there is little access to debt capital for biotech firms.

The game also suggests that UK management and investors have mindsets adapted to constrained financial circumstances. They design businesses to fit the financial environment rather than seeking the environment that their business needs. They discount early valuations because of the inflexible later-stage financial circumstances. Their low expectations become self-fulfilling prophecies. In contrast, US management looks to build a sustainable business from the outset, and investors get higher returns as a consequence.

Was any of this new, or unexpected? Not really. Players recommended initiatives such as collective investment funds to encourage larger, longerterm investment, better training for investment analysts, reform of UK tax to attract successful US and UK executives into the sector, and the creation of a leadership/mentor program. Another suggestion was to convene boot camps for UK entrepreneurs, part of which would involve role playing in a 'safe' learning environment where business failure would neither stigmatize nor traumatize the participating CEOs.

But perhaps the main take-home message is that it is just plain simpler to go where investors better understand biotech-the United States. In the real world, US companies spend on average three times as much on R\&D and have access to ten times more late-stage financing than UK companies. Indeed, some UK companies already have gotten that message: the reverse mergers of Dundee-based Cyclacel and Cambridge-based Solexa into, respectively, Xcyte Therapies (Seattle) and Lynx (now Illumina; Hayward, California) illustrate the point.

Which begs the question: why not take UK life science discoveries and concepts west sooner? In other words, do your science in the United Kingdom and spin-offs in the United States. This would seem the best option for UK entrepreneurs, who would be able to realize the full potential of their products, and for UK patients, who would get the resulting therapies sooner. The answer is, of course, that the UK government might find that rather hard to swallow. 